\title{
NO LONGER ELITE? OBSERVATIONS ON CONFERENCE INTERPRETING, COVID-19, AND THE STATUS OF THE POST-PANDEMIC PROFESSION
}

\author{
Antony HOYTE-WEST \\ Independent scholar, United Kingdom \\ E-mail: antony.hoyte.west@gmail.com
}

\begin{abstract}
This overview explores the impact of the ongoing COVID-19 pandemic and the associated restrictions on the professional status of the conference interpreting profession, paying specific attention to the EU context. With international conferences cancelled or transformed into online events, employment prospects for many conference interpreters have been affected sharply as the profession adapts to the new reality. In the first instance, historical and contemporary aspects of the conference interpreting profession are outlined, including the key role that international organisations played in its development as well as the growing level of scholarly interest in the profession and in conference interpreters themselves. Using information obtained primarily from language industry media sources, this is complemented by an overview of the impact of COVID-19 on the profession, with a particular focus on the EU and its accredited freelance conference interpreters during the pandemic. In addition, issues regarding technological changes - including the shift to remote simultaneous interpreting - are also outlined, with reference to some of the legal and ergonomic implications of this move. The impact on education and professional development is also touched upon, as well as the move towards a more holistic approach to interpreting settings in research and practice. Finally, given the preliminary nature of this overview, suggestions for further empirically-based research projects following the COVID-19 pandemic are offered.
\end{abstract}

KEYWORDS: conference interpreting, elite sociology, professional status, conference interpreters, remote simultaneous interpreting, COVID-19, coronavirus

\section{Introductory remarks}

Since it was officially declared on 11 March 2020 (World Health Organisation, 2020), the COVID-19 coronavirus pandemic has profoundly affected almost every sphere of human existence. With numerous public health restrictions in force, the advent of international travel bans and curtails on social mixing served as a death knell for face-to-face international conferences, and by extension, for the prospects of the conference interpreters who were employed - often on a freelance basis - to provide multilingual support at such events. With conferences and meetings either cancelled or moved to online platforms, the conference interpreting profession has consequently been forced to adapt accordingly. Although research on the impact of COVID-19 on the interpreting profession has been conducted, this has largely focused on practical aspects relating directly to aspects of training (such as the teaching of conference interpreting online) and technological changes (such as remote simultaneous interpreting) during the crisis, as several of the projected panel sessions at the upcoming European Society of Translation Studies congress* illustrate (University of Oslo, 2021). Comparatively little attention to date, however, has been focused on the potential ramifications of the pandemic on the wider professional status of the occupation as a whole. This contribution, therefore, aims to provide a brief exploratory overview of the impact of the COVID-19 pandemic on the current situation and potential development of the conference interpreting profession, with a focus on the relevant European Union (EU) context. Based primarily on the analysis of online sources and scholarly literature, it builds on the author's previous work on sociological aspects of the translational professions, thereby intending to provide a starting point for further discussions of this timely and relevant issue.

\section{The conference interpreting profession: origins and status}

Although various dates have been suggested as a possible genesis for the profession, it is generally agreed that the Nuremberg Trials (1945-1946) were the first major international event where simultaneous interpreting was used. With the horrors of the Nazi atrocities attracting the attention of the global media, the court's interpreters were also in the spotlight for their linguistic accomplishments. As noted in Behr (2015), the pioneering use of this form of interpreting meant that there were significant difficulties in finding the necessary personnel with the requisite skills. Indeed, given that there was then no simultaneous interpreter training course available, only around five percent of initial applicants made

\footnotetext{
${ }^{*}$ Scheduled to be held from 22-24 June 2022 at the University of Oslo and Oslo Metropolitan University, Norway.
} 
DOI: https://doi.org/10.37708/ezs.swu.bg.v20i1.9

the grade. Accordingly, those first conference interpreters relied on pure natural talent, which led to the origin of the myth that the skills of simultaneous interpreting were somehow innate and could not be taught. This combination of intellectual prowess combined with the proximity to power and influence led, therefore, to certain popular notions regarding the high prestige of conference interpreters.

Building on the success of the multilingual provision offered at Nuremberg, simultaneous interpreting was adopted by the newly-formed United Nations (UN), where it also proved challenging to source potential interpreters (Baigorri-Jalón, 2004). Nonetheless, as outlined in Thiéry (2015), the putative profession was bolstered by the formation of the Association Internationale des Interprètes de Conférence (AIIC) in 1953, which to this day remains the preeminent international professional organisation of conference interpreters. At the institutional level, it helps to ensure that standards are maintained, including with regard to working conditions, remuneration and professional domicile. Simultaneous interpreting was also taken up by the institutions of the EU in the late 1950s, where adherence to the organisation's founding concepts of multilingualism - and thus the equality of all EU official languages - has remained strong over the past six decades. This fidelity has meant that the number of languages required for interpretation purposes has grown from four to twenty-four, a figure which, as outlined by the author elsewhere, includes formerly minoritised languages such as Irish. As highlighted by Apostolou (2011, pp. 97-99), this means that the EU is now the largest employer of conference interpreters worldwide, with hundreds of in-house staff interpreters and thousands of accredited freelancers. Indeed, in its role as "a driving force" (Valdeón, 2021, p. 444), the EU context has had a significant influence on the development of the wider conference interpreting profession, and not solely in terms of the breadth and scope of the linguistic provision required. As noted by Pym (2000), the EU's institutional quality demands gave rise to an almost caste-like system, with the training of conference interpreters viewed largely as the in-house responsibility of relevant interpreting directorates. However, as Donovan (2011) highlights, this in-house model was dismantled and conference interpreter training is now largely undertaken by a network of university translation and interpreting departments across Europe. Indeed, the success of this collaboration is proof that, unlike the myth so widespread of seven decades ago, the skills of simultaneous interpreting can in fact be taught.

Turning to research in translation and interpreting studies, recent years have seen more and more interest in sociological aspects of the translational professions. In foregrounding translators and interpreters themselves, this move towards Translator Studies - outlined by leading scholars such as Gambier (2007) and Chesterman (2009) - has placed practitioners as the main objects of interest. Accordingly, relevant research projects have involved analyses of the professional status of translators and (conference) interpreters, including landmark international projects such as Pym, Grin, Sfreddo, \& Chan (2012) and Gentile (2015), as well as numerous case studies based on specific countries (for example, see Y1lmaz-Gümüş, 2018; Giustini, 2021; Ruokonen \& Svahn, 2021) or on particular international organisations (e.g. Dam \& Zethsen, 2013, 2014). In addition, recent work has also been conducted regarding the notion of elite identity among the translational professions, including Bednárová-Gibová \& Majherová's (2021) examination of academic literary translators in the Slovak context, as well as the author's current project on the intersection of the conference interpreting profession with elite sociology. Though the theoretical basis for the author's study proved that there were good grounds for conference interpreters to be considered an elite according to the sociological framework posited by Khan (2012), this was not borne out by the results of the empirical survey conducted before the COVID-19 pandemic, which illustrated that practitioners did not view themselves as being members of an elite (Hoyte-West, 2021). As such, despite the enduring popular image of conference interpreting as an elite profession, it is therefore clear that practitioners have somewhat different views. Nonetheless, as highlighted in several publications by and about conference interpreters (for example, see Harding, 2014; Beckwith, 2016; Naimushin, 2019), members of the profession still play an important and active role at the highest echelons of international diplomacy, business, and government.

\section{Conference interpreting and COVID-19}

As noted in the introduction to this article, the lack of face-to-face international conferences and meetings during the various waves of the COVID-19 pandemic has had correspondingly negative implications for conference interpreters and their employment prospects, leading one language industry- 
focused consulting firm to observe that "conference interpreting has been obliterated" (Nimdzi Insights, 2020). With many freelance professionals dependent on regular interpreting work from international organisations such as the EU, their major income source disappeared almost overnight. Accordingly, the situation of EU-accredited freelance conference interpreters was widely reported not only in the language industry press, but also in mainstream media outlets such as Euractiv, Deutsche Welle, and Euronews (e.g. Angelova, 2020; Nack, 2020; Koutsokosta, 2020). Indeed, the EU's response to the situation was criticised for an ostensible lack of solidarity, with its two main employers of freelance conference interpreters, the European Commission and the European Parliament, seemingly taking different approaches in this regard (for more information, see Marking, 2020a). It was reported that the institutional response to the cancelled or rescheduled interpreting contracts apparently proved confusing, and although some financial and training support was made available by the EU institutions, negotiating the relevant eligibility requirements appeared to be complex. As portrayed in the media coverage (e.g. Nack, 2020; Marking, 2020b), many freelance conference interpreters - including those who had been working for the EU institutions for decades - apparently felt like they had been discarded with precious little assistance or support. In fact, in response to the European Commission's offer of a relevant financial measure for eligible freelancers, a small demonstration of around 70 dissatisfied freelance conference interpreters took place outside the main European Parliament building in Brussels in June 2020 (Marking, 2020c). Concern about the general situation also reached a Member of the European Parliament, and a question for written answer regarding the financial and contractual arrangements for freelance interpreters was delivered to the European Commission (European Parliament, 2020a), leading to a reply from the relevant commissioner outlining the actions taken and reiterating the European Commission's commitment to multilingual communication (European Parliament, 2020b). As such, though the whole situation resulted in increased visibility for the wider profession, this was arguably not for the most positive of reasons. Indeed, it brought to public attention the at-times precarious nature of the freelance conference interpreting profession in general, even for practitioners working for institutions as prominent and prestigious as those of the EU, an organisation which - as outlined in the previous section - has played a fundamental role in the development and spread of the conference interpreting profession over the last six decades.

Though the move towards virtual conferences and remote simultaneous interpreting technologies had been anticipated before the COVID-19 pandemic (for more information, see Ziegler \& Gigliobianco, 2018; Albarino, 2019; Bond, 2019), the resultant impossibility of face-to-face meetings accelerated this shift considerably, both on the private market and with the international organisations. Consequently, the adoption of location-independent simultaneous interpreting technologies skyrocketed both among individual practitioners - who were either working from home, or from socalled interpreting 'hubs' (for more information, see Chaves, 2020) - as well as among the international organisations. Yet, the technology did not always provide an ideal solution. Indeed, the potential legal, ergonomic, and privacy-related implications of the usage of remote simultaneous interpreting platforms had been highlighted before the pandemic took hold (Rosado Professional Solutions, 2019). Understandably these gained greater prominence, especially with regard to the demands of simultaneous interpreting at the institutional level, leading AIIC to update and expand its range of guidelines and recommendations on the issue (for more information, see AIIC, 2021). For example, as noted in Chaoui's (2020) interview with the Chief Interpreter at the UN in Geneva, issues included challenges not only with sound quality, internet speed, and even the different way that UN delegates interacted and communicated on screen vis à vis in person. Similar aspects, including the possibilities of distractions and the challenges of teamwork at a distance (conference interpreters typically work at least in pairs) were also highlighted by profiles of UN interpreters adapting to the reality of working from home (United Nations, 2020). At the European Parliament, concerns were raised about the transfer and storage of meeting-related data by remote simultaneous interpreting platforms based outside of the EU (Albarino, 2021a). However, as illustrated by wider institutional responses to the situation (e.g. Albarino, 2021b; Marking, 2021), it appears clear that the online or hybrid meetings and events - and by extension, provision of remote or hybrid conference interpreting services - will continue even after the pandemic, be it for environmental, logistical, or other reasons. Another factor, too, will involve the challenges posed by increasing technological advances - for example, by the use of AI-related technologies as applied to simultaneous interpreting. Therefore, with regard to the notion of 
occupational status within the conference interpreting profession, it remains to be seen how much the move towards online modalities will impact practitioners in the long term.

The COVID-19 pandemic - and the corresponding shift to online interpreting modalities - has also influenced the training and development of budding conference interpreters. As alluded to previously, the EU institutions play an important role in the training of future practitioners and collaborate with a range of selected partner institutions. To that end, initiatives such as the Knowledge Centre on Interpretation (European Commission, 2021a) bring together professional expertise, research insights, and technological know-how. In addition, the Knowledge Centre on Interpretation provides a forum for wider discussion among interpreters and interpreter trainers from all professional backgrounds. As such, its activities are not only restricted to spoken-language conference interpreting, but also include other forms of interpreting such as community interpreting and sign language interpreting. In broadening the field, this more holistic approach reflects wider professional developments such as AIIC's recognition of sign language conference interpreters (de Wit, Crasborn, \& Napier, 2021), as well as a recent call from academia to move towards a broader comparative approach within the discipline of interpreting studies itself (Downie, 2021). As previously mentioned, in the light of the EU's perceived treatment of its freelance conference interpreters during the pandemic, it could be argued that this broadening of the field could also be reflected in the workplace. Given the clear message that institutionally-oriented freelance conference interpreters may no longer be able to depend just on the international organisations as a primary source of income, the changing professional reality may also encourage - or require - practitioners to develop activities in other areas of the translational professions, be it in other forms of spoken or signed-language interpreting, or in written translation.

\section{Concluding remarks}

In the light of the developments outlined above, this exploratory contribution has aimed to provide an overview of the situation within the conference interpreting profession at the present time. Having contextualised the historical and scholarly background, relevant institutional factors were outlined, which included reference to the EU's pandemic-related response regarding its contracted freelance conference interpreters, a factor which highlighted the precarity of the profession not only among its practitioners, but also raised awareness among the wider public. Although the author's previous studies illustrated that practitioners generally did not view themselves as being members of the elite, further empirical research is required to ascertain the long-term impact of this situation. Subsequently, technological-related aspects of the move to online meetings and conferences were briefly defined, including possible legal and health-related issues, as well as other practicalities that could affect the future status of conference interpreters and their profession. Finally, issues of training and of moves towards a wider approach to different interpreting modes and settings were also touched upon.

Regarding the COVID-19 pandemic, it remains too early at the time of writing (autumn 2021) to speculate on how the epidemiological situation will develop over the months and years to come. Though public health restrictions appear to be easing in many parts of the world, it is important to note that the threat posed by variants of COVID-19 continues to remain omnipresent. Though - at least in certain countries - face-to-face conferences and meetings are returning, it remains to be seen how this will impact conference interpreters and their professional status. In terms of academic perspectives on the issue, it has been posited that there are several relevant sociologically-oriented studies currently in progress. An example is a recent wide-ranging practitioner-based online survey on the scope and impact of the shift to remote simultaneous interpreting. Conducted by Collard \& Buján (2021), the preliminary findings were summarised on the Knowledge Centre for Interpretation (European Commission, 2021b) and in the language industry press (Albarino, 2021c) and will doubtlessly prove influential for subsequent research and practice in interpreting studies. Indeed, there are many questions to be explored regarding the future direction of the profession, involving not only practical considerations regarding working conditions and the use of relevant technologies, but also aspects relating to the education, training, and professional development of conference interpreters. As such, it is clear that there is a strong need for additional sociologically-based studies of the conference interpreting profession as it continues to evolve in the post-pandemic world. 
DOI: https://doi.org/10.37708/ezs.swu.bg.v20i1.9

\section{REFERENCES:}

AIIC (2021)

Albarino, S. (2019)

Albarino, S. (2021a)

Albarino, S. (2021b)

Albarino, S. (2021c)

Angelova, K. (2020)

Apostolou, F. (2011)

Baigorri-Jalón, J. (2004)

Beckwith, T. (2016)

Bednárová-Gibová, K., and Majherová, M. (2021)

Behr, M. (2015)

Bond, E. (2019)

Chaoui, P. (2020)

Chaves, S. (2020)

Chesterman, A. (2009)

Collard, C., and Buján, M. (2021)

Dam, H., and Zethsen, K. (2013)

Dam, H., and Zethsen, K. (2014)

Donovan, C. (2011)
AIIC and distance interpreting.

$<$ https://aiic.org/site/world/about/profession/distanceinterpreting $>$ (08.10.2021)

UN to host bake-off for remote interpreting platforms, NMT, speech-to-text. // Slator (24 October) <https://slator.com/un-to-host-bake-off-for-remoteinterpreting-platforms-nmt-speech-to-text/> (08.10.2021)

Behind the scenes of the European Parliament's pivot to remote interpreting. // Slator (18 February) <https://slator.com/behind-the-scenes-of-theeuropean-parliaments-pivot-to-remote-interpreting/> (08.10.2021)

UN seeks 'qualified providers' of remote simultaneous interpreting. // Slator (8 January) <https://slator.com/un-seeks-qualified-providers-of-remotesimultaneous-interpreting/> (08.10.2021)

Remote simultaneous interpreting 'more difficult' for $83 \%$ of interpreters, survey finds. // Slator (26 April) $<$ https://slator.com/remote-simultaneousinterpreting-more-difficult-for-83-of-interpreters-survey-finds/> (08.10.2021)

Key EU workers - interpreters - left on brink of survival during COVID. // Euractiv (4 June) <https://www.euractiv.com/section/economyjobs/news/key-eu-workers-interpreters-left-on-brink-of-survival-duringcovid/> (08.10.2021)

Introduction: Interpreting and translation in the EU. // Gramma: Journal of Theory and Criticism, 19, pp. 95-110. https://doi.org/10.26262/gramma.v19i0.6328

Interpreters at the United Nations: A history. Salamanca: Ediciones Universidad Salamanca. 184 pp.

An interview with Lynn Visson, retired United Nations interpreter. // The ATA Chronicle, 45 (5), pp. 25-27. <https://www.atachronicle.online/none/an-interview-with-lynn-visson-retired-unitednations-interpreter/> (08.10.2021)

Academic literary translators: a happy 'elite' or not? The Translator, 27 (2), pp. 167-189. https://doi.org/10.1080/13556509.2021.1872921

Nuremberg trial. In F. Pöchhacker (ed.) Routledge Encyclopedia of Interpreting Studies. London: Routledge. pp. 288-289.

EU gives in-principle green light to use of remote interpreting platforms. // Slator (26 July) $<$ https://slator.com/eu-gives-in-principle-green-light-to-useof-remote-interpreting-platforms/> $(08.10 .2021)$

Remote interpreting. // UN Today (31 August). $<$ https://untoday.org/remoteinterpretation/> $(08.10 .2021)$

Remote simultaneous interpreting hubs or platforms: What's the best option? // The ATA Chronicle, 49 (4), pp. 25-28. <https://www.atachronicle.online/featured/remote-simultaneous-interpreting-hubs-or-

platforms-whats-the-best-option/> $(08.10 .2021)$

The name and nature of Translator Studies. // Hermes - Journal of Language and Communication Studies, 42, pp. 13-29.

ESIT research project on remote simultaneous interpreting $<\underline{\text { https://www.researchgate.net/project/ESIT-research-project-on-remote- }}$ simultaneous-interpreting $>(08.10 .2021)$

Conference interpreters - the stars of the translation profession? : A study of the occupational status of Danish EU interpreters as compared to Danish EU translators. // Interpreting, $15 \quad$ (2), pp. 229-259. https://doi.org/10.1075/intp.15.2.04dam

Translators in international organizations: A special breed of high-status professionals? Danish EU translators as a case in point. In C.V. Angelelli (ed.) The Sociological Turn in Translation and Interpreting Studies. Amsterdam: John Benjamins Publishing Company, pp. 93-113.

Interpreter training, diversification and flexibility: The role of recruiting organisations. // Studia Universitatis Babes-Bolyai Philologia, 56 (1), pp. 525. 
DOI: https://doi.org/10.37708/ezs.swu.bg.v20i1.9

Downie, J. (2021)

\author{
European Commission \\ (2021a)
}

European Commission (2021b)

European Parliament (2020a)

European Parliament (2020b)

Gambier, Y. (2007)

Gentile, P. (2013)

Giustini, D. (2021)

Harding, L. (2014)

Hoyte-West, A. (2021)

Khan, S. (2012)

Koutsokosta, E. (2020)

Marking, M. (2020a)

Marking, M. (2020b)

Marking, M. (2020c)

Marking, M. (2021)

Nack, C. (2020)
Interpreting is interpreting: Why we need to leave behind interpreting settings to discover Comparative Interpreting Studies. // Translation and Interpreting Studies, $16 \quad$ (3), $\quad$ pp. 325-346. https://doi.org/10.1075/tis.20006.dow

Knowledge Centre on Interpretation.

$<$ https://ec.europa.eu/education/knowledge-centreinterpretation/knowledge-centre-interpretation en $>(08.10 .2021)$

ESIT research project on remote simultaneous interpreting. $<$ https://ec.europa.eu/education/knowledge-centre-interpretation/news/esitresearch-project-remote-simultaneous-interpreting en $>(08.10 .2021)$

Financial support for the Commissions' interpreters. Question for written answer E-003345/2020/rev.1 to the Commission. Rule 138.
Witold
Jan
Waszczykowski
(ECR).

$<$ https://www.europarl.europa.eu/doceo/document/E-9-2020003345 EN.html> $(08.10 .2021)$

Financial support for the Commissions' interpreters. Answer given by $\mathrm{Mr}$ Hahn on behalf of the European Commission.

Question reference: E-003345/2020.

$<$ https://www.europarl.europa.eu/doceo/document/E-9-2020-003345ASW EN.html> $(08.10 .2021)$

Y at-il place pour une socio-traductologie? In M. Wolf \& A. Fukari, (eds). Constructing a Sociology of Translation. Amsterdam: John Benjamins Publishing Company, pp. 205-217.

The status of conference interpreters: A global survey into the profession. // Rivista internazionale di tecnica della traduzione - International Journal of Translation, 15, pp. 63-82.

Haken conference interpreters in Japan: Exploring status through the sociology of work and of professions. // Interpreting and Society. [Online First] https://doi.org/10.1177/27523810211057447

A word in your ear: the interpreters who speak for world leaders. // The Guardian $(25$ July).

$<$ https://www.theguardian.com/world/2014/jul/25/interpreters-worldevents-gorbachev-reagan-deng-xiaoping-ahmadinejad $>$ (08.10.2021)

At the top of the tree? Surveying conference interpreters as an elite. // Studies About Languages, 38, pp. 29-42. https://doi.org/10.5755/j01.sal.1.38.28068 The sociology of elites. // Annual Review of Sociology, 38, pp. 361-377. https://doi.org/10.1146/annurev-soc-071811-145542

Coronavirus: Freelance EU interpreters left out of work, call on institutions for emergency support. // Euronews (4 June)

$<$ https://www.euronews.com/2020/06/04/coronavirus-freelance-euinterpreters-left-out-of-work-call-on-institutions-for-emergency> (08.10.2021)

As meetings rise again, two EU institutions treat contract interpreters differently. // Slator (8 October)

$<$ https://slator.com/as-meetings-rise-again-two-eu-institutions-treatcontract-interpreters-differently/> $(08.10 .2021)$

Contract interpreters 'puzzled' and 'hurt' by EU offer. // Slator (5 June) $<$ https://slator.com/contract-interpreters-puzzled-and-hurt-by-eu-offer/> (08.10.2021)

Contract interpreters rally over lack of support from EU. // Slator (19 June) $<$ https://slator.com/contract-interpreters-rally-over-lack-of-support-from$\underline{\mathrm{eu} />}(08.10 .2021)$

Genoveva Ruiz Calavera is the European Commission's new Chief Interpreter. // Slator (13 April) <https://slator.com/genoveva-ruiz-calaverais-the-european-commissions-new-chief-interpreter/> (08.10.2021)

Coronavirus crisis: EU interpreters left in the lurch. // Deutsche Welle (14 June) <https://www.dw.com/en/coronavirus-crisis-eu-interpreters-left-inthe-lurch/a-53798494> (08.10.2021) 
DOI: https://doi.org/10.37708/ezs.swu.bg.v20i1.9

Naimushin, B. (2019)

Nimdzi Insights (2020)

Pym, A. (2000)

Pym, A., Grin, F., Sfreddo,

C., and Chan, A. (2012)

Rosado Professional

Solutions (2019)

Ruokonen, M., and Svahn, E. (2021)

Thiéry, C. (2015)

United Nations (2020)

University of Oslo (2021)

Valdeón, R. (2021)

de Wit, M., Crasborn, O., and Napier, J. (2021)

World Health Organisation (2020)

Yılmaz-Gümüș, V. (2018)

Ziegler, K., and

Gigliobianco, S. (2018)
Interviews with translators and interpreters: Boris Naimushin. // Russian Journal of Linguistics, 23 (2), pp. 584-590.

Interpreting in times of COVID-19 $<$ https://www.nimdzi.com/interpretingin-times-of-covid-19/> (08.10.2021)

The European Union and its future languages: Questions for language policies and translation theories. // Across Languages and Cultures, 1(1), pp. $1-17$.

The status of the translation profession in the European Union. Luxembourg: Publications Office of the European Union. 168 pp.

The very real dangers of remote simultaneous interpreting from our home. // The Professional Interpreter (19 October) $<$ https://rpstranslations.wordpress.com/2019/10/17/the-very-real-dangersof-remote-simultaneous-interpreting-from-our-home/> (08.10.2021)

Comparative research into translator status: Finland and Sweden as a case in point, // Perspectives: Studies in Translation Theory and Practice. [Online First] https://doi.org/10.1080/0907676X.2021.1953546

AIIC. In F. Pöchhacker (ed.) Routledge Encyclopedia of Interpreting Studies. London: Routledge. pp. 13-15.

Portraits: UN interpreters adapt to new work modes during COVID-19 $<$ https://www.un.org/en/coronavirus/portraits-un-interpreters-adapt-newwork-modes-during-covid-19> $>(08.10 .2021)$

$10^{\text {th }}$ EST Congress: Advancing translation studies.

$<$ https://www.hf.uio.no/english/research/news-and-

events/events/conferences/est22/> (08.10.2021)

Perspectives on interpreting. // Perspectives: Studies in Translation Theory and Practice. 29 (4), pp. 441-453. https://doi.org/10.1080/0907676X.2021.1922130

Interpreting international sign: mapping the interpreter's profile. // The Interpreter and Translator Trainer. 15 (2), pp. 205-224. https://doi.org/10.1080/1750399X.2020.1868172

WHO Director-General's opening remarks at the media briefing on COVID$19-11 \quad$ March $2020 \quad<$ https://www.who.int/directorgeneral/speeches/detail/who-director-general-s-opening-remarks-at-themedia-briefing-on-covid-19---11-march-2020> (08.10.2021)

Solidity and professionalization of translation: Turkey as a case in point. // HERMES - Journal of Language and Communication in Business, 58, pp. 43-63.

Present? Remote? Remotely present! New technological approaches to remote simultaneous conference interpreting. In C. Fantinuoli (ed.) Interpreting and Technology. Berlin: Language Science Press, pp. 119-139. 